\title{
ANALISIS PENERAPAN METODE RGEC GUNA MENILAI TINGKAT KESEHATAN PERBANKAN SYARIAH TAHUN 2015-2017 (STUDI KASUS PADA PT. BANK CENTRAL ASIA SYARIAH)
}

\author{
Ratna Kurnia Sari ${ }^{1}$, Husni Mubarok ${ }^{2}$ \\ ${ }^{1,2)}$ Fakultas Teknologi Informasi, Universitas Bina Sarana Informatika Tegal
}

\begin{abstract}
In the economic system, banking has an important role in, supporting the economic progress of a country. In Indonesia alone, banking is known to be of two types, namely conventional banks and Islamic banks. Conventional banks usually refer to the interest system, which is most likely to be affected by the crisis. Whereas Islamic banks refer more to the profit sharing system and approach the community and reduce the risk or monetary fluctuation. The purpose of this study was to look at the health level of PT. Bank Central Asia Syariah using the RGEC method which includes risk profile, good corporate governance, earning and capital for 3 years. The result of the study in general showed that the health level of PT. Bank Central Asia Syariah in term of RGEC in 2015-2016 is in the position of composite rank 3 in a fairly healthy condition. Whereas in 2017 it was in the position of composite rank 2 in a healthy state. And to maintain public trust as the owner of the funds, stakeholders, and the government as supervisors, PT. Bank Central Asia Syariah is expected to be able to improve the ability of assets, capital management, and operational income, so that the quality of bank profits can be maintained and even improved.
\end{abstract}

Keywords

Correspondence to

: Analysis, PT. Bank Central Asia Syariah, RGEC Method

:ratna.rus@bsi.ac.id

\section{PENDAHULUAN}

Pada sistem perekonomian, perbankan memiliki peranan penting dalam menunjang kemajuan ekonomi suatu negara. Hal ini membuat pelaku usaha perbankan harus mengoptimalkan penggunaan dana maupun teknologi yang dimiliki sehingga mampu mencapai efektivitas dan efisiensi baik dari sisi produksi, distribusi, maupun konsumsi. Di Indonesia sendiri, perbankan dikenal menjadi dua macam, yaitu bank konvesional dan bank syariah.Bank konvensional biasanya lebih mengacu kepada sistem bunga, di mana kemungkinan besar mampu terkena dampak krisis.Sedangkan bank syariah lebih mengacu pada sistem bagi hasil dan melakukan pendekatan kepada masyarakat serta mengurangi resiko atau fluktuasi moneter. Hal tersebut tentunya akan membawa dampak positif maupun negatif dalam dunia perbankan. Peristiwa tersebut terjadi karena adanya peningkatan daya saing antar perbankan.Sehingga dapat memicu dan memotivasi bank itu sendiri untuk menjadi lebih baik ke depannya.Guna membangun hubungan yang baik dengan masyarakat, bank sendiri harus memiliki tingkat kesehatan yang baik pula, supaya tingkat kepercayaan masyarakat terhadap bank menjadi tinggi.

Berdasarkan Surat Edaran Bank Indonesia No. 13/24/DPNP tanggal 25 Oktober 2011, bank diwajibkan melakukan penilaian sendiri secara berkala terhadap tingkat kesehatannya dan mengambil langkah-langkah perbaikan secara efektif dengan menggunakan penilaian terhadap faktor meliputi risk profile, good corporate governance, earnings, dan capital yang disingkat dengan istilah RGEC. Pada prinsipnya, tingkat kesehatan, pengelolaan bank, serta kelangsungan usaha bank 
merupakan tanggung jawab sepenuhnya dari pihak manajemen bank.

Oleh karena itu, bank wajib memelihara dan memperbaiki tingkat kesehatannya dengan menerapkan prinsip kehati-hatian dan manajemen risiko dalam melaksanakan kegiatan usahanya termasuk melakukan penilaian sendiri secara berkala terhadap tingkat kesehatannya dan mengambil langkah perbaikan secara efektif. Di pihak lain, Bank Indonesia bertugas mengevaluasi, menilai tingkat kesehatan bank dan melakukan tindakan pengawasan yang diperlukan dalam rangka menjaga stabilitas sistem keuangan. Tujuan Penelitian:

1. Menganalisis tingkat kesehatan PT. Bank Central Asia Syariah ditinjau dari aspek Risk Profile periode 2015-2017

2. Menganalisis tingkat kesehatan PT. Bank Central Asia Syariah ditinjau dari aspek Good Corporate Governance periode 2015-2017

3. Menganalisis tingkat kesehatan PT. Bank Central Asia Syariah ditinjau dari aspek Earning periode 2015-2017

4. Menganalisis tingkat kesehatan PT. Bank Central Asia Syariah ditinjau dari aspek Capital periode 2015-2017

\section{METODE PENELITIAN}

Jenis Penelitian

Jenis penelitian yang digunakan berupa penelitian deskriptif komparatif, yaitu dengan meneliti laporan keuangan per-tahun dengan mengunakan metode RGEC, di mana pada laporan keuangan yang lalu dibandingkan dengan laporan keuangan lainnya sehingga dapat diketahui tingkat kesehatan perbankan pada PT. Bank Central Asia Syariah.

\section{Jenis dan Sumber Data}

Dalam penelitian ini jenis data yang digunakan adalah data kualitatif yaitu meliputi profil perusahaan dan laporan keuangan tahun 2015-2017.Sedangkan sumber data yang digunakan adalah data sekunder yang berupa dokumen laporan keuangan perbankan syariah dari tahun 20152017 yang diperoleh dari websitewww.bcasyariah.co.id yang telah dipublikasikan.

Teknik Analisis Data

Teknik analisis data yang digunakan adalah teknik analisis kuantitatif terdiri dari laporan keuangan perbankan yang meliputi neraca dan laporan laba rugi. Data tersebut akan digunakan sebagai alat pembanding antara tingkat kesehatan perbankan satu dengan perbankan lain yang sejenis untuk menunjukkan kondisi kesehatan perbankan dengan menggunakan metode RGEC. Data yang akan diperoleh merupakan hasil perhitungan atas variabel-variabel kesehatan perbankan. Adapun teknik analisis yang dipakai dalam penelitian ini adalah risk profile, good corporate governance, earnings dan capital.

\section{HASIL PENELITIAN}

Penerapan Metode RGEC yaitu risk profile (profil resiko), governance (tata kelola perusahaan), earnings (pendapatan), dancapital (permodalan) dalam menganalisis tingkat kesehatan PT. Bank Central Asia Syariah tahun 2015-2017.

1. Risk Profile

a. Risiko Pembiayaan

Penelitian ini untuk mengetahui risiko pembiayaan dihitung menggunakan rasio NPF (Non Performing Financing) yaitu pembiayaan yang diberikan kepada pihak ketiga (tidak termasuk pembiayaan kepada bank lain) yang merupakan kualitas pembiayaan bermasalah dengan kriteria kurang lancar, masih diragukan dan macet. Ratio NPF dapat dihitung dengan membandingkan pembiayaan bermasalah dengan total pembiayaan dan dikalikan 100 . Tujuannya untuk mengukur tingkat permasalahn pembiayaan yang dihadapi oleh bank. Semakin kecil ratio NPF maka akan 
semakin baik pembiayaan suatu bank. Ratio NPF dinyatakan dalam bentuk presentase (\%) dengan menggunakan skala ratio.

\begin{tabular}{|c|c|c|c|c|}
\hline NFF & $=$ & 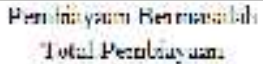 & $\mathrm{x}$ & $100 \%$ \\
\hline
\end{tabular}

b. Risiko Likuiditas

Ratio FDR (Financing to Deposit Ratio) yaitu ratio pembiayaan yang diberikan kepada pihak ketiga dalam rupiah dan valuta asing, tidak termasuk pembiayaan kepada bank lain, namun terhadap dana pihak ketiga yang mencakup giro, tabungan dan deposito. Penelitian ini menghitung ratio FDR dengan membandingkan besarnya pinjaman yang diberikan dengan jumlah dana pihak ketiga. Rasio yang besar menunjukkan bahwa suatu bank meminjamkan seluruh dananya atau tidak liquid. Sebaliknya ratio yang kecil menunjukan bank yang liquid dengan kelebihan kapasitas dana yang siap untuk dibiayai. Ratio FDR dinyatakan dalam bentuk persentase (\%) dengan menggunakan skala ratio

\begin{tabular}{|c|c|c|c|c|}
\hline FDR & $=$ & 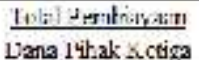 & $x$ & $-10 \%$ \\
\hline
\end{tabular}

TABEL 1. Hasil Perhitungan Risk Profile PT. BCA Syariah Periode 2015-2017

\begin{tabular}{lcccc}
\hline \multirow{2}{*}{ Ratio } & \multicolumn{3}{c}{ Tahun } & $\begin{array}{c}\text { Rata- } \\
\text { Rata }\end{array}$ \\
\cline { 2 - 4 } & 2015 & 2016 & 2017 & \\
\hline Risk & & & & \\
Profile & & & & \\
\hline & $\begin{array}{c}0.5 \\
\%\end{array}$ & $0.2 \%$ & $\begin{array}{c}0.04 \\
\%\end{array}$ & $0.24 \%$ \\
\hline - NPF & $\begin{array}{c}0.24 \\
\text { N }\end{array}$ & $\begin{array}{c}90.1 \\
\%\end{array}$ & $\begin{array}{c}88.5 \\
\%\end{array}$ & 1 \\
\hline
\end{tabular}

\section{Good Corporate Governance}

Pelaksanaan CGC berpedoman pada Peraturan Bank Indonesia No.11/33/PBI/2009 tanggal 7 Desember 2009 dan Surat Edaran Bank Indonesia No.12/13/DPbS tanggal 30 April 2010 tentang pelaksanaan Good Corporate Governance bagi Bank Umum
Syariah dan Unit Usaha Syariah dan

Peraturan Otoritas Jasa Keuangan No.8/POJK.03/2014 tentang Penilaian Tingkat Kesehatan Bank Umum Syariah dan Unit Usaha Syariah. PT.Bank Central Asia Syariah berkewajiban melaksanakan penilaian sendiri (self assessment) atas pelaksanaan GoodCorporate

Governancedengan mengacu pada peraturan yang berlaku.Pelaksanaan GCG harus berpedoman pada 5 prinsip dasar yaitu transparansi, akuntabilitas, professional, pertanggungjawaban, dan kewajaran.

TABEL 2. Hasil Perhitungan GCG PT. BCA Syariah Periode 2015-2017

\begin{tabular}{ccc} 
Tahun & Peringkat & Keterangan \\
\hline 2015 & 1 & Sangat Sehat \\
\hline 2016 & 1 & Sangat Sehat \\
\hline 2017 & 1 & Sangat Sehat \\
\hline
\end{tabular}

\section{Earnings}

a. ROA

Ratio ROA (Return On Asset) yaitu pengembalian atas asset merupakan rasio yang menunjukkan seberapa besar kontribusi asset dalam menciptakan laba kotor. Ratio ini digunakan untuk mengukur seberapa besar jumlah laba sebelum pajak yang akan dihasilkan dari setiap rupiah dana yang tertanam dalam rata-rata total asset. Semakin tinggi hasil pengembalian atas asset berarti semakin tinggi pula jumlah laba yang dihasilkan dari setiap rupiah dana yang tertanam dalam rata-rata total asset. Semakin rendah hasil pengembalian atas asset berarti semakin rendah pula jumlah laba yang dihasilkan dari setiap rupiah dana yang tertanam dalam rata-rata total asset.

\begin{tabular}{|c|c|c|c|}
\hline Ron & 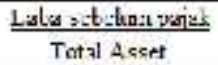 & $x$ & $100 \%$ \\
\hline
\end{tabular}

b. ROE

Ratio ROE (Return On Equity) adalah ratio yang digunakan untuk mengukur kemampuan modal disetor bank dalam 
Vol. XVII No. 1 | Bulan J anuari Tahun 2020

menghasilkan laba bersih. Ratio ROE dihitung dengan membandingkan laba bersih dengan rata-rata modal disetor.Semakin besar ratio ROE maka semakin besar kemampuan modal disetor bank dalam menghasilkan laba bagi pemegang saham semakin besar.

\begin{tabular}{|c|c|c|c|}
\hline $\mathrm{kel}=$ & $\frac{\mathrm{I}_{3} b_{\mathrm{a}} \text { setelah pajak }}{\text { Tal Equtv }}$ & $x$ & $150 \%$ \\
\hline
\end{tabular}

c. BOPO

Beban operasional terhadap pendapatan operasional adalah ratio yang digunakan untuk mengukur tingkat efisien dan kemampuan bank dalam melakukan kegiatan operasinya.

\begin{tabular}{|c|c|c|}
\hline so & & Debar Oper asional \\
\hline
\end{tabular}

TABEL 3. Hasil Perhitungan Earnings PT. BCA Syariah Periode 2015-2017

\begin{tabular}{ccccc}
\hline \multirow{2}{*}{ Ratio } & \multicolumn{3}{c}{ Tahun } & $\begin{array}{c}\text { Rata- } \\
\text { Rata }\end{array}$ \\
\cline { 2 - 5 } & 2015 & 2016 & 2017 & \\
\hline Earning & & & & \\
\hline & $\begin{array}{c}1.0 \\
\%\end{array}$ & $1.1 \%$ & $1.2 \%$ & $3.3 \%$ \\
\hline - ROA & $\begin{array}{c}3.1 \\
\%\end{array}$ & $3.5 \%$ & $4.3 \%$ & $3.63 \%$ \\
\hline - ROE & $\begin{array}{c}92.5 \\
\%\end{array}$ & $\begin{array}{c}92.2 \\
\%\end{array}$ & $\begin{array}{c}87.2 \\
\%\end{array}$ & $90.63 \%$ \\
\hline - BOPO & $\begin{array}{c}\text { B } \\
\text { B }\end{array}$ & & &
\end{tabular}

\section{Capital}

Penilaian terhadap faktor permodalan meliputi evaluasi terhadap kecukupan permodalan dan kecukupan pengelolaan permodalan.Penilaian permodalan menggunakan Capital Adequacy Ratio (CAR). CAR merupakan salah satu komponen factor permodalan adalah kecukupan modal yang digunakan untuk menguji kecukupan modal bank.

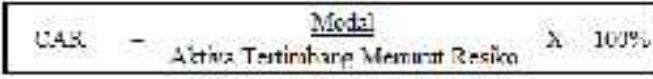

TABEL 4. Hasil Perhitungan Capital PT. BCA Syariah Periode 2015-2017

\begin{tabular}{ccccc}
\hline Ratio & \multicolumn{3}{c}{ Tahun } & $\begin{array}{c}\text { Rata- } \\
\text { Rata }\end{array}$ \\
\cline { 2 - 5 } & 2015 & 2016 & 2017 & \\
\hline Capital & & & & \\
\hline - CAR & $\begin{array}{c}34.3 \\
\%\end{array}$ & $\begin{array}{c}36.7 \\
\%\end{array}$ & $\begin{array}{c}29.4 \\
\%\end{array}$ & $33.46 \%$ \\
\hline
\end{tabular}

\section{PEMBAHASAN}

Dari tabel terlampir dapat dijelaskan mengenai penerapan Metode RGEC pada PT. Bank Central Asia Syariah periode 20152017 adalah sebagai berikut :

1. Risk Profile (Risiko Profil)

Indikator risk profile untuk mengukur kinerja keuangan Bank Umum Syariah diwakili non performing financing (NPF) yaitu untuk mengukur resiko kredit dan financing to debt ratio (FDR) untuk mengukur resiko likuiditas. Dari tabel diatas dapat diketahui bahwa di tahun 2015 Bank BCA Syariah memperoleh NPF sebesar 0,5 $\%, 2016$ sebesar 0,2 \% dan 2017 sebesar 0,04 $\%$ yang berarti tidak terdapat dana yang termasuk dalam pembiayaan kurang lancar, diragukan dan macet dari total pembiayaan yang diberikan bank. Karena semakin besar nilai NPF nya menunjukkan jika bank kurang baik dalam menyeleksi calon peminjam. Dan sesuai penetapan nilai komposit yang ada pada Surat Edaran Bank Indonesia memiliki NPF sebesar 1,50 \% dan termasuk dalam peringkat sangat sehat karena kurang dari 2 $\%$. Sedangkan untuk nilai FDR pada tahun 2015 sebesar 91,4 \%, 2016 sebesar 90,1\% dan 2017 sebesar 88,5\% yang berarti setiap dana yang dihimpun bank dapat mendukung pinjaman yang diberikan sebesar 91,4\%, $90,1 \%, 88,5 \%$ dari total pembiayaan yang diberikan, dalam hal ini bank dapat mengelola simpanan dalam bentuk pembiayaan sebesar 91,4\%, 90,1\%, 88,5\%. Sehingga kemampuan menghasilkan laba suatu bank akan meningkat seiring peningkatan pemberian kredit atau pembiayaan. Menurut penetapan nilai komposit yang ada pada Surat Edaran Bank Indonesia memiliki FDR sebesar 91,4\%, $90,1 \%, 88,5 \%$ dengan tingkat komposit 3 dan predikat cukup sehat karena melebihi $85 \%$ dan kurang dari $100 \%$. 
2. Good Corporate Governance (GCG)

Berdasarkan PBI Nomor

13/1/PBI/2011, bank umum wajib mempertimbangkan faktor GCG untuk menjamin adanya tata kelola manajemen yang baik sehingga dapat meningkatkan kinerja yang maksimal. Dari tabel dapat lihat bahwa dari tahun 2015-2017 Bank BCA Syariah memperoleh predikat sangat sehat dengan nilai komposit 1 . Hal ini dapat membuktikan bahwa bank BCA Syariah melakukan manajemen yang baik dan mengikuti prinsip-prinsip GCG sesuai dengan ketentuan yang sudah ditetapkan oleh Peraturan Bank Indonesia.

\section{Earnings (Rentabilitas)}

Komponen penilaian yang digunakan pada tahap ini adalah ROA, ROE dan BOPO, yaitu untuk mengukur keberhasilan manajemen dalam menghasilkan laba. Dari tabel dapat dilihat bahwa dari segi ROA Bank BCA Syariah di tahun 2015 memperoleh nilai sebesar 1,0\%, 2016 sebesar 1,1\% dan 2017 sebesar $1,2 \%$. Itu artinya semakin tinggi persentase maka tingkat produktivitas akan semakin meningkat. Dimana sesuai dengan penetapan nilai komposit yang ada di Surat Edaran Bank Indonesia yaitu sebesar 1,0\%, $1,1 \%, 1,2 \%$ dengan tingkat komposit 3 dan predikat cukup sehat karena melebihi $0,5 \%$ serta kurang dari $1,25 \%$. Sedangkan untuk ROE, ditahun 2015 memperoleh 3,1\%, 2016 sebesar 3,5\% dan 2017 sebesar 4,3\%. Dimana semakin tinggi persentase maka tingkat produktivitas akan semakin meningkat serta sesuai dengan penetapan nilai komposit yang ada di Surat Edaran Bank Indonesia yaitu sebesar 3,1\%, 3,5\%, 4,3\% dengan tingkat komposit 4 dan predikat kurang sehat karena nilai kurang dari 5\%. Untuk BOPO sendiri, Bank BCA Syariah di tahun 2015 memperoleh nilai sebesar 92,5\%, 2016 sebesar $92,2 \%$ dan 2017 sebesar 87,2\% yang digunakan untuk kegiatan operasional bank. Semakin kecil prosentase BOPO, maka semakin efisien biaya operasional yang dikeluarkan bank.Sebaliknya, semakin besar presentase BOPO maka menunjukkan kurangnya kemampuan bank dalam menekan biaya operasional dan dapat menimbulkan kerugian bank. Sesuai Surat Edaran Bank Indonesia, yaitu dengan memiliki BOPO sebesar 92,5\%, 92,2\% dan 87,2\%, maka berada pada tingkat komposit 5 yaitu dengan predikat tidak sehat karena melebihi batas $89 \%$.

\section{Capital (Permodalan)}

Rasio untuk menilai permodalan ini adalah CAR, yaitu faktor permodalan yang didasarkan pada perbandingan jumlah modal terhadap total aktiva tertimbang menurut risiko. Berdasarkan tabel diatas dapat dilihat bahwa Bank BCA Syariah memiliki CAR sebesar $34,3 \%$ di tahun 2015, 36,7\% tahun 2016, dan $29,4 \%$ tahun 2017. Sehingga dapat diartikan bahwa seluruh permodalan yang dimiliki bank tersebut dapat mengantisipasi kemungkinan resiko kredit. Di mana sesuai Surat Edaran Bank Indonesia bahwa nilai CAR sebesar 34,3\%, 36,7\% dan 29,4\% berada pada predikat sangat sehat atau tingkat komposit 1 karena memiliki nilai melebihi batas minimal yaitu $12 \%$

\section{SIMPULAN}

Berdasarkan pengolahan data dan hasil analisis, maka diperoleh kesimpulan bahwa tingkat kesehatan pada PT. Bank Central Asia Syariah tahun 2015 sampai 2016 dapat dikatakan memiliki kategori CUKUP SEHAT sedangkan pada tahun 2017 masuk kategori SEHAT yang diukur menggunakan pendekatan RGEC (Risk Profile, Good Corporate Governance, Earning dan Capital). Pernyataan kesimpulan tersebut didukung dengan data-data berikut :

1. Nilai risk profile yang terdiri dari Non Performing Financing (NPF) memiliki nilai komposit sesuai pada Surat Edaran Bank Indonesia yaitu sebesar 1,50\% dan termasuk dalam peringkat sangat sehat karena kurang dari $2 \%$. Hal ini bisa terlihat dari nilai yang didapat dari tahun 2015 sampai 2017, masing-msing sebesar $0,5 \%, 0,2 \%$, dan $0,04 \%$. Sedangkan untukFinancing to Deposit Ratio (FDR) memiliki nilai komposit sesuai pada Surat Edaran Bank Indonesia yaitu sebesar 91,4\%, 90,1\%, 88,5\% 
padatahun 2015sampai 2017dengan tingkat komposit 3 dan predikat cukup sehat karena melebihi $85 \%$ dan kurang dari $100 \%$.

2. Nilai Good Corporate Governance (GCG) dari hasil self assessment yang dipublikasikan oleh PT. Bank Central Asia Syariah melalui halaman internet resmi, tahun 2015-2017 berada pada peringkat komposit 1 yang secara umum menunjukkan CGC sangat sehat.

3. Nilai Earnings yang terdiri dari Return On Asset (ROA) dimana memiliki nilai komposit sesuai Surat Edaran Bank Indonesia yaitu sebesar $1,0 \%, 1,1 \%$, 1,2\% (tahun 2015-2017) dengan tingkat komposit 3 dan predikat cukup sehat karena melebihi $0,5 \%$ serta kurang dari 1,25\%. SedangkanReturn On Equity $(R O E)$ memiliki nilai komposit sesuai Surat Edaran Bank Indonesia yaitu sebesar 3,1\%,3,5\%, 4,3\% (tahun 20152017) dengan tingkat komposit 4 dan predikat kurang sehat karena nilai kurang dari 5\% dan BOPO memiliki nilai komposit sesuai Surat Edaran Bank Indonesia yaitu sebesar 92,5\%, 92,2\% dan 87,2\% (tahun 2015-2017), maka berada pada tingkat komposit 5 yaitu dengan predikat tidak sehat karena melebihi batas $89 \%$.

4. Capital dari hasil penelitian ini secara umum berada pada peringkat komposit sangat sehat. Hal ini terlihat dari nilai CAR sebesar 34,3\%, 36,7\% dan 29,4\% (tahun 2015-2017) berada pada komposit 1 karena memiliki nilai melebihi batas minimal yaitu $12 \%$.

5. Secara umum, tingkat kesehatan PT. Bank Central Asia Syariah dari aspek RGEC pada tahun 2015-2016 berada pada posisi peringkat komposit 3 dalam keadaan cukup sehat. Sedangkan pada tahun 2017 berada pada posisi peringkat komposit 2 dalam keadaan sehat.

Saran
Berdasarkan hasil penelitian dan pembahasan di atas, maka ada beberapa saran yang dapat disampaikan, antara lain :

1. Tingkat kesehatan yang menunjukkan trend positif harus selalu terjaga untuk keberlangsungan aktivitas operasi bank. Menjaga kepercayaan masyarakat sebagai pemilik dana, stakeholder, dan pemerintah sebagai pengawas, PT. Bank Central Asia Syariah dapat meningkatkan kemampuan asset, pengelolaan modal, serta pendapatan operasional. Sehingga kualitas laba bank dapat dipertahankan bahkan ditingkatkan.

2. Melihat kemampuan menghasilkan laba yang masih fluktuatif, PT. Bank Central Asia Syariah harus meningkatkan kinerja diiringi dengan manajemen yang baik agar dana yang ada dapat menjadi produktif.

3. Untuk calon nasabah maupun para nasabah PT. Bank Central Asia Syariah tidak perlu khawatir untuk menyimpan dana atau melakukan pembiayaan. Karena modal yang dimiliki oleh PT. Bank Central Asia Syariah dengan predikat sehat mampu menangani jika terjadi kerugian.

\section{DAFTAR PUSTAKA}

Bank Indonesia, 2011, Peraturan Bank Indonesia Nomor 13/1/PBI/2011 tentang Penilaian Tingkat Kesehatan Bank Umum, Jakarta, Bank Indonesia

Bank Indonesia, 2011, Surat Edaran Nomor 13/24/DPNP tanggal 25 Oktober 2011 tentang Penilaian Tingkat Kesehatan Bank Umum, Jakarta, Bank Indonesia

Dwi, Suwiknyo, 2016, Analisis Laporan Keuangan Perbankan Syariah, Pustaka Pelajar, Yogyakarta

Hasan, Muhammad Iqbal, 2016, Analisis Tingkat Kesehatan Bank dengan 
Metode RGEC pada PT. Bank

Syariah Bukopin 2013-2015, Skripsi

Perbankan Syariah STAIN Curup

Jumingan, 2011, Analisis Laporan Keuangan, PT. Bumi Aksara, Jakarta

Kasmir, 2008, Analisis Laporan Keuangan, Edisi Pertama, Cetakan Pertama, Penerbit : Rajawali Pers, Jakarta
Laporan Keuangan PT. Bank Central Asia Syariah, www.bcasyariah.co.id

Undang-Undang Republik Indonesia Nomor 10 Tahun 1998 Tentang Perbankan, diakses dari www.bphn.go.id

V.Winata Sujarweni, 2017, Analisis Laporan Keuangan, Pustaka Baru Press, Yogyakarta 


\section{LAMPIRAN}

TABEL 5. Peringkat Komposit Tingkat Kesehatan PT. BCA Syariah Periode 2015

\begin{tabular}{|c|c|c|c|c|c|c|c|c|c|c|c|}
\hline \multirow{2}{*}{ Tahun } & \multirow{2}{*}{ Komponen } & \multirow{2}{*}{ Ratio } & \multirow{2}{*}{$\begin{array}{c}\text { Ratio } \\
(\%) \\
\end{array}$} & \multicolumn{5}{|c|}{ Peringkat } & \multirow{2}{*}{ Kriteria } & \multirow{2}{*}{ Keterangan } & \multirow{2}{*}{ Komposit } \\
\hline & & & & 1 & 2 & 3 & 4 & 5 & & & \\
\hline \multirow{7}{*}{2015} & \multirow{2}{*}{ Risk Profile } & NPF & 0,52 & $\sqrt{ }$ & & & & & Sangat Sehat & \multirow{2}{*}{ Sehat } & \multirow{7}{*}{ Cukup Sehat } \\
\hline & & FDR & 91,39 & & & $\sqrt{ }$ & & & Cukup Sehat & & \\
\hline & CGC & & & $\sqrt{ }$ & & & & & Sangat Sehat & Sangat Sehat & \\
\hline & \multirow{3}{*}{ Earning } & $\mathrm{ROA}$ & 1,0 & & & $\sqrt{ }$ & & & Cukup Sehat & \multirow{3}{*}{ Kurang Sehat } & \\
\hline & & ROE & 3,1 & & & & $\sqrt{ }$ & & Kurang Sehat & & \\
\hline & & BOPO & 92,5 & & & & & $\sqrt{ }$ & Tidak Sehat & & \\
\hline & Capital & CAR & 34,3 & $\sqrt{ }$ & & & & & Sangat Sehat & Sangat Sehat & \\
\hline
\end{tabular}

TABEL 6. Peringkat Komposit Tingkat Kesehatan PT. BCA Syariah Periode 2016

\begin{tabular}{|c|c|c|c|c|c|c|c|c|c|c|c|}
\hline \multirow{2}{*}{ Tahun } & \multirow{2}{*}{ Komponen } & \multirow{2}{*}{ Ratio } & \multirow{2}{*}{$\begin{array}{c}\text { Ratio } \\
(\%) \\
\end{array}$} & \multicolumn{5}{|c|}{ Peringkat } & \multirow{2}{*}{ Kriteria } & \multirow{2}{*}{ Keterangan } & \multirow{2}{*}{ Komposit } \\
\hline & & & & 1 & 2 & 3 & 4 & 5 & & & \\
\hline \multirow{7}{*}{2016} & \multirow{2}{*}{ Risk Profile } & NPF & 0,2 & $\sqrt{ }$ & & & & & Sangat Sehat & \multirow{2}{*}{ Sehat } & \multirow{7}{*}{ Cukup Sehat } \\
\hline & & FDR & 90,1 & & & $\sqrt{ }$ & & & Cukup Sehat & & \\
\hline & CGC & & & $\sqrt{ }$ & & & & & Sangat Sehat & Sangat Sehat & \\
\hline & \multirow{3}{*}{ Earning } & ROA & 1,1 & & & $\sqrt{ }$ & & & Cukup Sehat & \multirow{3}{*}{ Kurang Sehat } & \\
\hline & & ROE & 3,5 & & & & $\sqrt{ }$ & & Kurang Sehat & & \\
\hline & & BOPO & 92,2 & & & & & $\sqrt{ }$ & Tidak Sehat & & \\
\hline & Capital & CAR & 36,7 & $\sqrt{ }$ & & & & & Sangat Sehat & Sangat Sehat & \\
\hline
\end{tabular}

TABEL 7. Peringkat Komposit Tingkat Kesehatan PT. BCA Syariah Periode 2017

\begin{tabular}{|c|c|c|c|c|c|c|c|c|c|c|c|}
\hline \multirow{2}{*}{ Tahun } & \multirow{2}{*}{ Komponen } & \multirow{2}{*}{ Ratio } & \multirow{2}{*}{$\begin{array}{l}\text { Ratio } \\
(\%)\end{array}$} & \multicolumn{5}{|c|}{ Peringkat } & \multirow{2}{*}{ Kriteria } & \multirow{2}{*}{ Keterangan } & \multirow{2}{*}{ Komposit } \\
\hline & & & & 1 & 2 & 3 & 4 & 5 & & & \\
\hline \multirow{7}{*}{2017} & \multirow{2}{*}{ Risk Profile } & NPF & 0,04 & $\sqrt{ }$ & & & & & Sangat Sehat & \multirow{2}{*}{ Sehat } & \multirow{7}{*}{ Sehat } \\
\hline & & FDR & 88,5 & & & $\sqrt{ }$ & & & Cukup Sehat & & \\
\hline & CGC & & & $\sqrt{ }$ & & & & & Sangat Sehat & Sangat Sehat & \\
\hline & \multirow{3}{*}{ Earning } & ROA & 1,2 & & & $\sqrt{ }$ & & & Cukup Sehat & \multirow{3}{*}{ Cukup Sehat } & \\
\hline & & ROE & 4,3 & & & & $\sqrt{ }$ & & Cukup Sehat & & \\
\hline & & BOPO & 87,2 & & & & $\sqrt{ }$ & & Kurang Sehat & & \\
\hline & Capital & CAR & 29,4 & $\sqrt{ }$ & & & & & Sangat Sehat & Sangat Sehat & \\
\hline
\end{tabular}


Balance: Economic, Business, Management, and Accounting J ournal Vol. XVII No. 1 | Bulan J anuari Tahun 2020 